STUDIA PRAWNO-EKONOMICZNE, T. CXVIII, 2021

PL ISSN 0081-6841; e-ISSN 2450-8179 s. 119-136

https://doi.org/10.26485/SPE/2021/118/7

\title{
Łukasz STERNOWSKI*
}

(iD https://orcid.org/0000-0001-5867-7776

\section{„HANDLOWE ASPEKTY WŁASNOŚCI INTELEKTUALNEJ” JAKO CZĘŚĆ WSPÓLNEJ POLITYKI HANDLOWEJ - KONSEKWENCJE DLA BEZPOŚREDNIEJ SKUTECZNOŚCI TRIPS}

\begin{abstract}
Abstrakt
Przedmiot badań: Nieustanny rozwój technologiczny sprawia, że znaczenie własności intelektualnej rośnie, a ochrona prawna m.in. wynalazków nabiera ogromnego znaczenia, zwłaszcza dla państw, których gospodarki oparte są na innowacyjności. Na przestrzeni lat Wspólna Polityka Handlowa Unii Europejskiej podlegała zmianom traktatowym, co skutkowało m.in. ewolucją jej zakresu przedmiotowego. Również charakter kompetencji Wspólnot Europejskich, a następnie Unii Europejskiej w tym zakresie zmieniał się. Jednym z najistotniejszych, a zarazem powodującym najwięcej kontrowersji jest kwestia skutku bezpośredniego TRIPS w państwach członkowskich Unii Europejskiej. Istotność tego zagadnienia wynika z postanowień TRIPS, które gwarantują minimalny zakres ochrony praw własności intelektualnej.

Cel badawczy: Autor zmierza do ustalenia, jakim zakresem kompetencji dysponuje Unia Europejska w odniesieniu do TRIPS. Artykuł ma na celu odpowiedzenie na pytanie - jak ewolucja Wspólnej Polityki Handlowej Unii Europejskiej wpłynęła na stosowanie TRIPS w państwach członkowskich Unii Europejskiej.

Metoda badawcza: W artykule wykorzystano głównie metody: formalno-dogmatyczną oraz historyczno-prawną. W zakresie badania orzecznictwa Trybunału Sprawiedliwości posłużono się metodą empiryczno-prawną.

Wyniki: Charakter kompetencji Wspólnot Europejskich, a następnie Unii Europejskiej w odniesieniu do Wspólnej Polityki Handlowej zmieniał się wraz ze zmianami postanowień traktatów. Od dnia wejścia w życie Traktatu z Lizbony (1.12.2009 r.) Wspólna Polityka Handlowa wchodzi w zakres jej kompetencji wyłącznych oraz obejmuje handlowe aspekty własności intelektualnej. Orzecznictwo Trybunału Sprawiedliwości potwierdziło, że TRIPS w całości objęty jest kompetencją UE, z czego mogłoby wynikać, że dla oceny skutku bezpośredniego jego postanowień miarodajne są - wbrew kontrowersjom w uprzednim stanie prawnym, gdy TRIPS miał charakter tzw. umowy mieszanej - unijne reguły skutku bezpośredniego. Z drugiej strony, Trybunał nie zdecydował się na zakwestionowanie dotychczasowego orzecznictwa w tym zakresie, co może

* Mgr, Kierownik Działu Ochrony Własności Intelektualnej, Cyfrowy Polsat S.A. Autor przygotowuje pracę doktorską na temat ewolucji statusu TRIPS w świetle zmian wprowadzonych we Wspólnej Polityce Handlowej UE na mocy Traktatu z Lizbony; e-mail: lukasz@sternowski.pl
\end{abstract}


prowadzić do wniosku, że odmowa skutku bezpośredniego TRIPS pozostaje w mocy. Niemniej problem stracił na znaczeniu praktycznym, bowiem postanowienia TRIPS zostały (po zakończeniu okresów przejściowych) recypowane do prawa krajowego państw członkowskich.

Słowa kluczowe: Unia Europejska, Trybunał Sprawiedliwości Unii Europejskiej, Traktat o Funkcjonowaniu Unii Europejskiej, prawo własności intelektualnej, patent.

\section{Wstęp}

Niniejszy artykuł omawia problematykę skutku bezpośredniego Porozumienia w sprawie Handlowych Aspektów Praw Własności Intelektualnej (ang. Agreement on Trade-Related Aspects of Intellectual Property Rights - TRIPS) ${ }^{1}$, które od wejścia w życie Traktatu z Lizbony ${ }^{2}$ objęte jest zakresem Wspólnej Polityki Handlowej (WPH), a co za tym idzie wyłączną kompetencją Unii. TRIPS, którego stronami są zarówno państwa członkowskie UE, jak również sama Unia do czasu wejścia $\mathrm{w}$ życie Traktatu z Lizbony uznawane było za tzw. umowę mieszaną, czyli wchodzącą w zakres kompetencji zarówno Unii, jak i państw członkowskich. $Z$ tego charakteru TRIPS wynikało odmawianie przez Trybunał Sprawiedliwości (TS) skutku bezpośredniego postanowieniom TRIPS, nie odmawiając przy tym państwom członkowskim możliwości stosowania postanowień TRIPS przez sądy krajowe (w zakresie kompetencji państw). Traktat z Lizbony poprzez rozszerzenie Wspólnej Polityki Handlowej (która wchodzi w zakres kompetencji wyłącznych UE), m.in. o handlowe aspekty własności intelektualnej, sprawił, że stanowisko Trybunału musiało ulec stosownej zmianie.

Niniejszy artykuł omawia w pierwszej kolejności rozwój zakresu przedmiotowego WPH oraz charakter kompetencji UE w tym zakresie. Następnie przedstawiono charakterystykę ogólną TRIPS oraz rozważania na temat konsekwencji zmiany stanu prawnego wraz z wejściem w życie Traktatu z Lizbony dla skutku bezpośredniego TRIPS. Finalnie artykuł ma na celu próbę odpowiedzi na pytanie, czy TRIPS odnosi skutek bezpośredni w państwach członkowskich UE.

Dz.U. L 336 z 23.12.1994 r., s. 214-233.

2 Traktat z Lizbony zmieniający Traktat o Unii Europejskiej i Traktat ustanawiający Wspólnotę Europejską, podpisany w Lizbonie dnia 13 grudnia 2007 r., wszedł w życie 1 grudnia 2009 r. 


\section{Zakres przedmiotowy Wspólnej Polityki Handlowej oraz charakter kompetencji UE w tym obszarze}

Wspólna Polityka Handlowa stanowi niezwykle istotny obszar rozwoju współpracy gospodarczej państw członkowskich Unii Europejskiej³ . Jej zakres przedmiotowy zmieniał się na przestrzeni lat wraz z kolejnymi traktatami rewizyjny$\mathrm{mi}^{4}$. Pierwotne postanowienia Traktatu ustanawiającego Europejską Wspólnotę Gospodarczą (TEWG) ${ }^{5}$ - art. 113 TEWG - wskazywały na następujący zakres przedmiotowy WPH: zmiany stawek celnych, zawieranie umów celnych i handlowych, ujednolicenie działań liberalizacyjnych, polityki eksportowej i działań chroniących handel podejmowanych w sytuacjach, w których dochodzi do dumpingu lub subsydiowania. W odniesieniu do kompetencji Wspólnoty w obszarze WPH Trybunał w wyroku w sprawie C-37 i 38/73 Indiamex ${ }^{6}$ wskazał jednoznacznie na wyłączność kompetencji WE, stwierdzając, że „realizacja Wspólnej Polityki Handlowej należy do wyłącznej jurysdykcji Wspólnoty"7. Podobne stanowisko Trybunał wyraził w opinii $1 / 75^{8}$, wskazując, że „nie można przyjąć, w obszarze [...] objętym wspólną polityką handlową, aby państwa członkowskie wykonywały kompetencję konkurencyjną do realizowanej przez Wspólnotę, zarówno w sferze wewnątrzwspólnotowej, jak i międzynarodowej”. Natomiast po przeanalizowaniu postanowień TRIPS, TS uznał, że co do zasady nie wchodzi ono w zakres WPH z wyjątkiem postanowień dotyczących wprowadzania do swobodnego obrotu towarów podrabianych, które uznał za wchodzące w zakres kompetencji wyłącznych $\mathrm{UE}^{9}$. Wobec powyższego, wynikającego przede wszystkim z mieszanego charakteru umów WTO, kompetencje WE miały charakter wyłączny jedynie w odniesieniu do regulacji obrotu towarami,

3 Ekonomiczny aspekt WPH został opisany w: A. Wróbel, Wspólna Polityka Handlowa Unii Europejskiej, Warszawa 2014. Znaczenie WPH dla rynku wewnętrznego UE zostało przedstawione w: M. Czermińska, Wspólna Polityka Handlowa Unii Europejskiej. Znaczenie dla ochrony jednolitego rynku wewnętrznego i międzynarodowego bezpieczeństwa ekonomicznego, Toruń 2019.

4 Więcej nt. zakresu i rozwoju WPH zob. G. Mazur, Wspólna Polityka Handlowa Unii Europejskiej, Warszawa 2017, s. 14-46.

5 Traktat ustanawiający Europejską Wspólnotę Gospodarczą podpisany 25 marca 1957 r. wszedł w życie 1 stycznia $1958 \mathrm{r}$.

6 Wyrok Trybunału C-38/73 z dnia 13 grudnia 1973 r. Social Fonds voor de Diamantarbeiders przeciwko NV Indiamex i Feitelijke Vereniging De Belder, ECLU:EU:C:1973:165.

Pkt 24 wyroku.

Opinia Trybunału 1/75 z dnia 11 listopada 1975 r., ECLI:EU:C:1975:145.

Pkt 71 opinii. 
natomiast charakter dzielony kompetencji WE obejmował kwestie związane ze świadczeniem usług oraz z prawami własności intelektualnej ${ }^{10}$.

Pierwsza znacząca zmiana zakresu kompetencji Wspólnoty w dziedzinie WPH została wprowadzona na mocy Traktatu z Amsterdamu, który dodał w art. 113 (który stał się art. 133) Traktatu ustanawiającego Wspólnotę Europejską (TWE) ${ }^{11}$ ust. 5, przyznając Radzie, działając jednomyślnie na wniosek Komisji i po konsultacji z Parlamentem, kompetencje do rozszerzenia działań w zakresie WPH na rokowania i umowy międzynarodowe w dziedzinie handlu usługami i ochrony własności intelektualnej. Wątpliwości w zakresie charakteru kompetencji Wspólnoty pojawily się po wydaniu przez Trybunał opinii 1/94 ${ }^{12}$, w której potwierdził on wyłączność kompetencji WE w zakresie handlu towarami ${ }^{13}$. Analizując zakres przedmiotowy GATS (Układ ogólny w sprawie handlu usługami), uznał, że jedynie transgraniczne dostarczanie usług (będące jedną z czterech form handlu usługami) wchodzi w zakres wyłącznej kompetencji Wspólnoty ${ }^{14}$.

Kolejny traktat rewizyjny - Traktat z Nicei ${ }^{15}$ zmienił ówczesny art. 133 TWE, nadając nowe brzmienie ust. 5 oraz dodając dwa nowe ustępy. Nowy ust. 5 TWE rozszerzył zastosowanie ust. 1-4 na „rokowania i zawieranie umów w dziedzinie handlu usługami i handlowych aspektów własności intelektualnej w zakresie, w jakim umowy te nie są objęte tymi ustępami i bez uszczerbku dla ustępu 6". Natomiast ust. 6 wskazuje, że z uwzględnieniem ust. 5 Rada może jednomyślnie na wniosek Komisji w procedurze konsultacji z Parlamentem „rozszerzyć zastosowanie ustępów 1-4 na rokowania i umowy międzynarodowe dotyczące praw własności intelektualnej w zakresie, w jakim nie są one objęte ustępem 5". Ust. 6 wprowadza również kategorię umów mieszanych do-

10 Więcej zob.: M. Górski, Wspólna Polityka Handlowa Unii Europejskiej. Aspekty prawne i instytucjonalne, Warszawa 2012, s. 10-13.

11 Traktat z Amsterdamu zmieniający Traktat o Unii Europejskiej, traktaty ustanawiające Wspólnoty Europejskie i niektóre związane z nimi akty, podpisany w Amsterdamie dnia 2 października 1997 r., wszedł w życie 1 maja 1999 r.

12 Opinia 1/94 Trybunału z dnia 15 listopada 1994 r., ECLI:EU:C:1994:384. Więcej nt. opinii zob.: J. Bourgeois, The EC in the WTO and Advisory Opinion 1/94: An Echternach Procession, Common Market Law Review 1995/32, s. 763-787; M. Hilf, The ECJ's Opinion 1/94 on the WTO, No surprise but Wise?, European Journal of International Law 1995/6, s. 245-259; T. Tridimas, The WTO and OECD Opinions, w: A. Dashwood, Ch. Hillion (red.), The general law of E.C. external relations, Sweet \& Maxwell, 2000, s. 48-60.

13 Pkt 34 opinii.

14 Pkt 53 opinii.

15 Traktat z Nicei zmieniający Traktat o Unii Europejskiej, traktaty ustanawiające Wspólnoty Europejskie i niektóre związane z nimi akty, podpisany w Nicei dnia 26 lutego 2001 r., wszedł w życie 1 kwietnia 2003 r. 
tyczących handlu usługami w dziedzinie kultury i audiowizualnymi, usługami edukacyjnymi oraz usługami socjalnymi i w zakresie zdrowia ludzkiego, które pozostają w obszarze kompetencji dzielonych. Tym samym mamy do czynienia z kompetencją dzieloną w dziedzinie usług (art. 133 ust. 5), z wyjątkiem usług, które związane są z handlem towarami (art. 133 ust. 1-4) i podobnie jak usługi transportowe (art. 133 ust. 6) podlegają wyłącznej kompetencji WE. Ust. 7 odnoszący się do umów międzynarodowych dotyczących praw własności intelektualnej stanowi, iż Rada mogła rozszerzać zastosowanie ust. 1-4 na negocjacje i umowy międzynarodowe dotyczące praw własności intelektualnej w zakresie, w jakim nie były one objęte ust. 5, który mówi o umowach dotyczących „handlowych aspektów" własności intelektualnej. Kompetencje WE w dziedzinie WPH miały zatem charakter niewyłączny (mieszany).

Wraz z wejściem w życie Traktatu z Lizbony zakres przedmiotowy WPH objął dwa nowe obszary: „handlowe aspekty własności intelektualnej” (wychodząc poza kompetencję i procedurę zawierania umów w tym zakresie) i „bezpośrednie inwestycje zagraniczne" (art. 207 ust. 1 Traktatu o Funkcjonowaniu Unii Europejskiej - TFUE). W kwestii kompetencji, w przeciwieństwie do zawiłego brzmienia art. 133 TWE, Traktat $\mathrm{z}$ Lizbony stanowi wprost $\mathrm{w}$ art. 3 ust. 1 lit. e), że Unia ma wyłączne kompetencje w dziedzinie WPH, przy czym należy mieć na uwadze brzmienie art. 207 ust. 6 TFUE, który zastrzega, że Unia, wykonując przyznane jej wyłączne uprawnienia w zakresie WPH, nie może prowadzić do naruszenia kompetencji państw członkowskich.

\section{Charakterystyka TRIPS}

TRIPS weszło w życie 1 stycznia 1995 r. ${ }^{16}$ jako jedna z umów międzynarodowych składających się na pakiet związany z ustanowieniem Światowej Organizacji Handlu (ang. World Trade Organization - WTO) ${ }^{17}$. Formalnie stanowi załącznik do umowy w sprawie ustanowienia WTO. Kraje rozwijające się oraz będące w okresie transformacji gospodarczej otrzymały możliwość skorzysta-

16 Dz.U. z 1995 r., nr 98, poz. 483, więcej nt. TRIPS zob.: C.M. Correa, Trade-Related Aspects of Intellectual Property Rights. A Commentary on The TRIPS Agreement, Oxford 2020; T. Targosz, Miejsce porozumienia TRIPS w prawie polskim, Kwartalnik Prawa Prywatnego 2005/XIV/3, s. 735-764.

17 Więcej nt. WTO zob.: P. Van den Bossche, W. Zdouc, The Law and Policy of the World Trade Organization, Cambridge University Press 2018. W chwili założenia WTO liczyła 112 członków, obecnie liczy 164. 
nia z okresów przejściowych, które wynosiły 5 lat, przy czym kraje najsłabiej rozwinięte mogły skorzystać z 10-letniego okresu przejściowego. Polska skorzystała z 5-letniego okresu przejściowego, w związku z czym TRIPS weszło w życie w Polsce w całości 1 stycznia $2000 \mathrm{r}$.

Zakres regulacji zawartych w TRIPS obejmujący kwestie odnoszące się do wszystkich praw własności intelektualnej, w skład których wchodzą zarówno prawa autorskie (ochrona wykonawców, producentów i organizacji nadawczych), jak również prawa własności przemysłowej (znaki towarowe, patenty, geograficzne oznaczenia pochodzenia towarów, topografie układów scalonych i wzory przemysłowe) jest znacznie bardziej kompleksowy niż w umowach międzynarodowych obowiązujących przed wejściem w życie TRIPS ${ }^{18}$. Wśród podstawowych zasad sformułowanych w TRIPS należy wskazać zasady: asymilacji, zwaną również zasadą traktowania narodowego, minimum ochrony oraz największego uprzywilejowania (art. 4 TRIPS) ${ }^{19}$.

TRIPS jest umową handlową mającą na celu promowanie wolnego handlu ${ }^{20}$, a własność intelektualna ma niewątpliwie istotne znaczenie z ekonomicznego punktu widzenia, stąd zagadnienie skutku bezpośredniego TRIPS ma istotne znaczenie praktyczne. Ani TRIPS, ani inne porozumienia stanowiące podstawę WTO nie wykluczają bezpośredniego stosowania swoich postanowień w państwach będących członkami WTO, a samo TRIPS wprost pozostawia swobodę w tym zakresie w art. $1^{21}$.

Jeśli chodzi o państwa członkowskie WE, a obecnie UE, to problem skutku bezpośredniego postanowień TRIPS związany był z charakterem tego porozumienia (z punktu widzenia prawa wspólnotowego) jako tzw. umowy miesza-

18 M. Czajkowska-Dąbrowska, Ochrona praw autorskich i pokrewnych na podstawie konwencji międzynarodowych, w: J. Barta (red.), System Prawa Prywatnego, t. 13, Prawo autorskie, Warszawa 2013, s. 1007.

19 Szczegółowy opis zasad zob. M. Czajkowska-Dąbrowska, Ochrona praw autorskich i pokrewnych na podstawie konwencji międzynarodowych, w: J. Barta (red.), System Prawa Prywatnego, t. 13, Prawo autorskie, Warszawa 2013, s. 1013-1017; R. Skubisz, Własność przemystowa w systemie prawa, w: R. Skubisz (red.), System Prawa Pywatnego, t. 14A, Prawo własności przemysłowej, Warszawa 2012, s. 18-19.

20 N. Pires de Carvalho, The TRIPS Regime of Patent Rights, Hague 2005, s. 40-43. Zob. Intangible Capital in Global Value, World Intellectual Property Report 2017, World Intellectual Property Organization; M.A. Weresa (red.), Własność intelektualna. Wybrane aspekty ekonomiczne, Warszawa 2009; R.D. Ryder, N.S. Sreenivasulu, The Economics of Intellectual Property and Economic Entrepreneurship of Copyrights, w: M.K. Sinha, V. Mahalwar, Copyright Law in the Digidal World. Challenges and Opportunities, Singapore 2017, s. 45-60.

21 Szczegółowy opis charakteru oraz cech TRIPS zob. T. Targosz, Miejsce porozumienia TRIPS w prawie polskim, Kwartalnik Prawa Prywatnego 2005/XIV/3, s. 743-748. 
nej. Oznaczało to, że skutek bezpośredni postanowień objętych kompetencją WE oceniany był stosownie do orzecznictwa Trybunału Sprawiedliwości (które konsekwentnie odmawiało takiego skutku postanowieniom GATT47, a następnie GATT95 oraz postanowieniom TRIPS w zakresie w stosowania prawa wspólnotowego), natomiast w pozostałym zakresie miarodajna była praktyka konstytucyjna poszczególnych państw, będących stronami TRIPS.

Wraz z objęciem na mocy Traktatu z Lizbony „handlowych aspektów własności intelektualnej" WPH i zarazem podporządkowaniem WPH wyłącznym kompetencjom UE powstały nowe ramy prawne. Zasadnicze znaczenie dla oceny TRIPS i tego punktu widzenia mają dwie kwestie - po pierwsze stwierdzenie, czy TRIPS objęty jest w całości zakresem WPH, a tym samym wyłączną kompetencją UE, po drugie - jakie ma to następstwa dla wywierania przez postanowienia TRIPS skutku bezpośredniego w państwach członkowskich UE.

\section{Czy TRIPS jest objęty zakresem WPH: wyrok Trybunału Sprawiedliwości w sprawie C-414/11 Daichii Sankyo}

Orzeczenie z dnia 18 lipca 2013 r. w sprawie C-414/1122 zostało wydane w trybie prejudycjalnym w odpowiedzi na pytania zadane przez Sąd Grecki w Atenach, które dotyczyły wykładni art. 27 i 70 TRIPS. Sprawa dotyczyła sporu pomiędzy spółkami Daichi Sankyo Co. Ltd i Sanofi-Aventis Deutschland GmbH a spółką Demo Anonymos Viomichaniki kai Emporiki Etairian Farmakon, która sprzedawała produkt generyczny o nazwie „Talerin”, w skład którego wchodziła substancja aktywna w postaci półhydratu lewofloksacyny, chroniona przez prawa patentowe Daichii Sankyo w postaci produktu farmaceutycznego o nazwie „Tavanic". Spór dotyczył kwestii, czy udzielone na podstawie rozporządzenia Rady nr 1768/92 23 dodatkowe świadectwo ochronne obejmowało substancję czynną produktu leczniczego, czy jedynie sam proces jego wytwarzania. Ze względu na brak zdolności patentowej substancji aktywnej produktu farmaceutycznego w dacie zgłoszenia wynalazku w Grecji patent dotyczył jedynie procesu wytwarzania produktu. Jednakże zastosowanie art. $27 \mathrm{w}$ związku z art. 70 TRIPS pozwoliłoby objąć ochroną również samą substancję aktywną. Sąd grecki skie-

22 Wyrok Trybunału C-414/11 z dnia 18 lipca 2013 r. w sprawie Daiichi Sankyo Co. Ltd., Sanofi-Aventis Deutschland GmbH przeciwko DEMO Anonymos Viomichaniki kai Emporiki Etairia Farmakon, ECLI:EU:C:2013:520.

23 Rozporządzenie Rady (EWG) nr 1768/92 z dnia 18 czerwca 1992 r. dotyczące stworzenia dodatkowego świadectwa ochronnego dla produktów leczniczych, OJ L 182, 2.7.1992 r., s. 1-5. 
rował do TSUE trzy pytania prejudycjalne. Pierwsze dotyczyło kwestii objęcia art. 27 TRIPS kompetencją państw członkowskich, a co za tym idzie uznania, że „państwa członkowskie mogą same uznać, że wspomniany przepis jest bezpośrednio skuteczny oraz czy sąd krajowy może bezpośrednio stosować ten przepis na warunkach przewidzianych w jego porządku prawnym". Drugie pytanie odnosiło się do problemu, czy wynalazek w postaci produktu farmaceutycznego stanowi przedmiot mający zdolność patentową w rozumieniu art. 27 TRIPS, a jeżeli tak, to jaki jest zakres przyznanej patentem ochrony. Trzecie pytanie dotyczyło kwestii, czy biorąc pod uwagę treść art. 27 i 70 TRIPS patent, który w chwili jego przyznania obejmował tylko proces wytworzenia produktu farmaceutycznego, po wejściu w życie TRIPS obejmuje również wynalazek w postaci produktu farmaceutycznego.

Najistotniejsze dla rozważań na temat skutku bezpośredniego TRIPS jest pytanie pierwsze, ponieważ odnosi się do kwestii, czy wejście w życie Traktatu z Lizbony oraz dodanie w jego art. 207 ust. 1 TFUE ,handlowych aspektów własności intelektualnej" do zakresu Wspólnej Polityki Handlowej, która zgodnie $\mathrm{z}$ art. 3 ust. 1 TFUE należy do wyłącznej kompetencji Unii oznacza, że TRIPS podlega wyłącznej kompetencji Unii. Co równie istotne, wyjaśnienia wymagała również kwestia kompetencji TSUE do interpretacji postanowień TRIPS, a konkretnie, czy nadal obowiązuje stanowisko Trybunału wyrażone w tym zakresie w wyroku z dnia 11 września 2007 r. w sprawie C-431/05 Merck Genéricos ${ }^{24}$. W wyroku tym Trybunał stwierdził, że „skoro porozumienie TRIPS zostało zawarte przez Wspólnotę i jej państwa członkowskie w ramach kompetencji wspólnej, to Trybunał, do którego wniesiono sprawę zgodnie z przepisami traktatu WE, a w szczególności art. $234 \mathrm{WE}$, jest właściwy do określenia zobowiązań, jakie przyjęła w ten sposób na siebie Wspólnota i do dokonania w tym celu wykładni postanowień porozumienia TRIPS"25. W sprawie C-414/11 Trybunał przychylił się do stanowiska Komisji Europejskiej i zmienił swoje wcześniejsze stanowisko, uznając, że TRIPS podlega w całości wyłącznej kompetencji Unii jako wchodzące w zakres Wspólnej Polityki Handlowej. Trybunał wskazał, że w związku z wejściem w życie Traktatu z Lizbony jego wcześniejsza argumentacja, przedstawiona w opinii 1/94 oraz w orzeczeniu w sprawie Merck straciła aktualność:

24 Wyrok Trybunału C-431/05 z dnia 11 września 2007 r., Merck Genéricos - Produtos Farmacêuticos Ltd przeciwko Merck \& Co. Inc. i Merck Sharp \& Dohme Ltd, ECLI:EU:C:2007:496.

25 Pkt 33 wyroku. 
Biorąc pod uwagę tę istotną ewolucję prawa pierwotnego, kwestię rozdziału kompetencji Unii od kompetencji państw członkowskich należy zbadać w świetle obecnie obowiązującego traktatu. Zatem ani opinia 1/94 z dnia 15 listopada 1994 r., w której Trybunał ustalił w świetle art. 113 traktatu WE, które postanowienia porozumienia TRIPS były objęte zakresem wspólnej polityki handlowej i w związku z tym wyłączną kompetencją Wspólnoty, ani wyrok w sprawie Merck, dokonujący w momencie, gdy art. 133 WE pozostawał w mocy, rozdziału wynikających z porozumienia TRIPS obowiązków spoczywających na Unii i obowiązków ciążących wyłącznie na państwach członkowskich, nie mają znaczenia dla określenia, w jakim stopniu, począwszy od wejścia w życie traktatu FUE, porozumienie TRIPS jest objęte zakresem wyłącznej kompetencji Unii w dziedzinie wspólnej polityki handloweje ${ }^{26}$.

Następnie Trybunał odniósł się do użytego w art. 207 ust. 1 TFUE pojęcia „handlowych aspektów własności intelektualnej”, wskazując, że „unijny akt prawny wchodzi w zakres wspólnej polityki handlowej, gdy dotyczy konkretnie wymiany międzynarodowej, to znaczy jego głównym zadaniem jest wspieranie, ułatwianie lub regulowanie wymiany handlowej oraz gdy wywiera on bezpośredni wpływ na obrót określonymi towarami" ${ }^{27}$. Trybunał uznał TRIPS za umowę spełniającą te kryteria, a także zauważył, że zbieżność pomiędzy tytułem TRIPS a sformułowaniem zawartym w art. 207 ust. 1 TFUE nie może być przypadkowa. Trybunał wskazał, że ,przewidując w art. 207 ust. 1 TFUE, że handlowe aspekty własności intelektualnej wchodzą teraz w pełni w zakres wspólnej polityki handlowej, autorzy traktatu FUE nie mogli nie być świadomi, że brzmienie fragmentu dodanego do tego postanowienia ma niemal dokładnie to samo brzmienie, co sam tytuł porozumienia TRIPS"28. Trybunał nie przychylił się również do stanowiska państw członkowskich twierdzących, że znaczna część TRIPS, w tym jego art. 27 zaliczają się do dziedziny rynku wewnętrznego. Trybunał w swojej argumentacji przywołał cele Porozumienia, do których zaliczył m.in. ograniczenie wypaczeń w handlu międzynarodowym oraz zagwarantowanie ochrony praw własności intelektualnej.

Trybunał wskazał, że TRIPS nie wchodzi w zakres wymiany handlowej w ramach rynku wewnętrznego, lecz do działań zewnętrznych Unii, a także, że

co prawda po wejściu w życie TFUE Unia nadal może regulować prawa własności intelektualnej na podstawie kompetencji należących do dziedziny rynku wewnętrznego, niemniej jednak akty przyjęte na tej podstawie i przeznaczone do obowiązywania konkretnie w Unii muszą przestrzegać norm dotyczących dostępności, zakresu i korzystania z praw własności intelektualnej zawartych w porozumieniu TRIPS, ponieważ

\footnotetext{
26 Pkt 48 wyroku.

27 Pkt 51 wyroku.

28 Pkt 55 wyroku.
} 
przeznaczeniem tych norm pozostaje - jak wcześniej - ujednolicenie pewnych zasad $w$ tej dziedzinie na poziomie światowym i ułatwienie wymiany międzynarodowej ${ }^{29}$.

Trybunał odrzucił również argumenty państw członkowskich podnoszących, że postanowienia co najmniej II części TRIPS (a więc również art. 27) należą do dziedziny rynku wewnętrznego, powołując się na art. 114 i 118 TFUE. TSUE stwierdził, że powyższa argumentacja nie uwzględnia w dostatecznym stopniu celu porozumienia TRIPS w ogólności i celu w szczególności jego części II ${ }^{30}$.

Powyższe rozważania Trybunału doprowadziły do przedstawienia następujących wniosków: 1) Art. 27 TRIPS należy do WPH; 2) Art. 27 TRIPS należy interpretować w ten sposób, że wynalazek w postaci produktu farmaceutycznego, takiego jak związek chemiczny będący składnikiem aktywnym produktu leczniczego, może - w braku odstępstw ustanowionych na podstawie art. 27 ust 2 i 3 stanowić przedmiot mający zdolność patentową, jeżeli spełnia on warunki określone w art. 27 ust. 1; 3) Patentu uzyskanego w wyniku zgłoszenia zawierającego opis wynalazku w postaci zarówno procesu wytworzenia produktu farmaceutycznego, jak i tego produktu jako takiego, który został jednak udzielony wyłącznie w odniesieniu do procesu wytworzenia, nie należy, z powodu zasad ustanowionych w art. 27 i 70 TRIPS, uważać, począwszy od dnia wejścia w życie tego porozumienia za obejmujący wynalazek w postaci tego produktu farmaceutycznego ${ }^{31}$.

Trybunał określił zatem pozycję TRIPS po wejściu w życie Traktatu z Lizbony i wbrew wcześniejszym stanowiskom uznał, że TRIPS wchodzi w zakres wspólnej polityki handlowej, a co za tym idzie, wchodzi w zakres wyłącznej kompetencji UE. Trybunał nie zdecydował się na wyjaśnienie, jaki ma to wpływ na kwestię skutku bezpośredniego postanowień TRIPS, pomimo że pytania prejudycjalne wprost się do tego problemu odnosiły, a Rzecznik Generalny poddał ten problem wnikliwej analizie w swojej opinii ${ }^{32}$.

Wyrok w sprawie Daichii Sankyo jest kluczowy dla interpretacji TRIPS, bowiem potwierdza objęcie go w całości wyłączną kompetencją Unii, a co za tym idzie Trybunał Sprawiedliwości jest właściwy do interpretacji postanowień TRIPS oraz uznania jego skutku bezpośredniego.

\footnotetext{
Pkt 59 wyroku.

Pkt 57 wyroku.

Pkt 84 wyroku.

32 Analiza Opinii Rzecznika Generalnego P.C. Villalona z dnia 31 stycznia 2013 r., zob: A. Nowicka, Wynalazki i ich ochrona - wybrane aspekty prawne i praktyczne, Prace z Prawa Własności Intelektualnej 2014/126, s. 100-101.
} 


\section{Konsekwencje dla wywierania skutku bezpośredniego postanowień TRIPS}

\subsection{Stan prawny przed i po wejściu w życie Traktatu z Lizbony}

Samo TRIPS dopuszcza stosowanie w sposób bezpośredni swoich postanowień poprzez pozostawienie decyzji w tym zakresie państwom, które przystąpiły do Porozumienia. Jednakże Trybunał Sprawiedliwości od lat siedemdziesiątych konsekwentnie odmawiał skutku bezpośredniego wpierw postanowieniom GATT47, a następnie prawu WTO, w tym postanowieniom TRIPS ${ }^{33}$. W swoich orzeczeniach (m.in. w sprawach C-21/72 International Fruit Company ${ }^{34}$, C-53/96 Hermes $^{35}$ oraz C-300/98 Dior $^{36}$ ) utrwalił pogląd, że osoba fizyczna lub podmiot prawny nie mają możliwości powoływania się na postanowienia prawa WTO w postępowaniach przed sądami krajowymi i sądami wspólnotowymi (unijnymi). Wykonywanie TRIPS będącego umową mieszaną, czyli taką, która swoim zakresem obejmuje regulacje podlegające zarówno kompetencjom UE, jak i państw członkowskich było więc pochodną podziału tych kompetencji w ramach UE. W zakresie objętym kompetencją wyłączną WE/EU skutek bezpośredni postanowień TRIPS był wyłączony, a w zakresie kompetencji dzielonych decydowała praktyka konstytucyjna państw członkowskich.

W Polsce do zagadnienia uznania skutku bezpośredniego TRIPS odniósł się Naczelny Sąd Administracyjny w wyroku z dnia 8 lutego 2006 r. w sprawie II GSK 54/05 37 , która dotyczyła wydłużenia okresu ochronnego na substancję chemiczną z 15 lat przewidzianych w art. 16 ustawy o wynalazczości ${ }^{38}$ do 20 lat wynikających $\mathrm{z}$ art. 33 TRIPS. Istotą problemu rozpatrywanego przez NSA było

33 Więcej zob. J. Barcz, W sprawie bezpośredniego skutku przepisów Porozumienia TRIPS w świetle prawa wspólnotowego (I), Europejski Przegląd Sądowy, luty 2006 r., s. 18-31 oraz J. Barcz, W sprawie bezpośredniego skutku przepisów Porozumienia TRIPS w świetle prawa wspólnotowego (II), Europejski Przegląd Sądowy, marzec 2006 r., s. 14-26.

34 Wyrok Trybunału w C-21/72 z dnia 12 grudnia 1972 r., International Fruit Company NV i inni przeciwko Produktschap voor Groenten en Fruit, ECLI:EU:C:1972:115.

35 Wyrok Trybunału w sprawie C-53/96 z dnia 16 czerwca 1998 r., Hermès International (société en commandite par actions) przeciwko FHT Marketing Choice BV, ECLI:EU:C:1998:292.

36 Wyrok Trybunału C-300/98 z dnia 14 grudnia 2000 r. Parfums Christian Dior SA przeciwko TUK Consultancy BV i Assco Gerüste GmbH i Rob van Dijk przeciwko Wilhelm Layher GmbH \& Co. KG i Layher BV, ECLI:EU:C:200:688.

37 Więcej nt. wyroku zob.: R. Skubisz, Glosa do wyroku Naczelnego Sądu Administracyjnego $z$ dnia 8 lutego 2006 r. (sygn. akt II GSK 54/05), Zeszyty Naukowe Sądownictwa Administracyjnego 2006/6, s. 152-162.

38 Ustawa z dnia 19 października 1972 r. o wynalazczości, Dz.U. z 1993 r., nr 26, poz. 117 ze zm. 
rozstrzygnięcie, czy art. 33 TRIPS stanowi normę o charakterze samowykonalnym i może być stosowany bezpośrednio przez sądy krajowe oraz organy administracji. NSA, opierając się na przesłankach samowykonalności przepisu w postaci zamiaru stron umowy oraz interpretacji literalnej, uznał, że zarówno art. 33 TRIPS, jak również art. 70 ust. 2 TRIPS mają charakter samowykonalny. Tym samym 20-letni okres ochronny ma zastosowanie i nie wymaga zastosowania żadnej dodatkowej decyzji administracyjnej.

Również Sąd Najwyższy rozpatrywał możliwość stosowania bezpośredniego TRIPS w orzeczeniu III CSK 112/05, w którym podobnie jak NSA uznał skutek bezpośredni TRIPS ${ }^{39}$.

Lista dziedzin objętych Wspólną Polityką Handlową zawarta w art. 207 ust. 1 nie stanowi katalogu zamkniętego, co dopuszcza szeroki zakres interpretacyjny. W efekcie Unia może zyskać uprawnienia, które nie zostały jej przypisane w chwili formułowania treści przepisu traktatu. Zmiana zakresu Wspólnej Polityki Handlowej spowodowała rewizję podejścia Trybunału do TRIPS. W świetle zmian wprowadzonych przez Traktat z Lizbony WPH należąca do kategorii stosunków zewnętrznych Unii, w tym handlowe aspekty własności intelektualnej, objęta jest zgodnie z art. 3 ust. 1 TFUE zakresem kompetencji wyłącznych UE.

\subsection{Wpływ wyroku C-414/11 Daichii Sankyo na stosowanie bezpośrednie TRIPS}

W swoim orzeczeniu Trybunał nie odniósł się w pełni do pytania pierwszego, które w swojej drugiej części brzmiało „czy państwa członkowskie mogą (same) uznać, że wspomniany przepis jest bezpośrednio skuteczny oraz czy sąd krajowy może bezpośrednio stosować ten przepis na warunkach przewidzianych w jego porządku prawnym?"40. Udzielając odpowiedzi na pytanie pierwsze, Trybunał wskazał, że z uwagi na odpowiedź udzieloną na pierwszą część tego pytania nie ma potrzeby badania drugiej jego części ${ }^{41}$. Wynika z tego, że Unia posiada kompetencje w zakresie określania bezpośredniego skutku postanowień TRIPS, która to kompetencja nie należy już do państw członkowskich. Może to oznaczać, że sądy krajowe powinny zmienić swoje orzecznictwo w tym zakresie. Jednakże Trybunał nie zdecydował się poruszyć tego problemu w swoim orzeczeniu. Skoro zatem wyrok w sprawie Daiichi nie zmienia stanowiska Try-

39 Zob. M. du Vall, P. Kostański, J. Ożegalska-Trybalska, P. Podrecki, E. Traple (red.), Prawo patentowe, Warszawa 2017, s. 164.

40 Pkt 32 wyroku.

41 Pkt 62 wyroku. 
bunału przedstawianego we wcześniejszym orzecznictwie, które wskazywało na brak skutku bezpośredniego TRIPS, wydaje się, że pozostaje ono aktualne. Natomiast mając na uwadze, że TRIPS objęte jest wyłączną kompetencją UE, zauważyć należy, że sądy krajowe nie mogą zastosować jego postanowień bezpośrednio, jednakże zobowiązane są do wykładni prawa krajowego zgodnie $\mathrm{z}$ duchem Porozumienia ${ }^{42}$.

Należy zauważyć, że istnieją sprzeczności pomiędzy orzeczeniem w sprawie Daiichi a wcześniejszym orzecznictwem Trybunału, dotyczącym TRIPS. Trybunał, orzekając w sprawie Daichii, mógł wykorzystać bogate rozważania i argumenty, dotyczące kompetencji ze swojej wcześniejszej opinii 1/94. Ponieważ Trybunał nie zdecydował się na taki krok, stwierdzając, że

ani ww. wyrok w sprawie Merck Genéricos - Produtos Farmacêuticos, dokonujący w momencie, gdy art. $133 \mathrm{WE}$ pozostawał w mocy, rozdziału wynikających z porozumienia TRIPS obowiązków spoczywających na Unii i obowiązków ciążących wyłącznie na państwach członkowskich, nie mają znaczenia dla określenia, w jakim stopniu, począwszy od wejścia w życie traktatu FUE, porozumienie TRIPS jest objęte zakresem wyłącznej kompetencji Unii w dziedzinie wspólnej polityki handlowej ${ }^{43}$.

Takie podejście Trybunału może prowadzić do krytycznej oceny, ponieważ wydaje się, że pełna analiza oparta na podstawie nowej definicji oraz historycznego kontekstu rozwoju zakresu WPH zamiast skupiania się na treści TRIPS oraz jego relacji z prawem WTO byłaby odpowiednia dla uzasadnienia rozważań w sprawie Daiichi.

Biorąc pod uwagę powyższe rozważania, należy zwrócić uwagę na jeszcze jedną kwestię związaną z wyrokiem w spawie C-414/11 i zadać pytanie, czy wyrok ten nie prowadzi do quasi-harmonizacji materialnego prawa patentowego w UE poprzez stosowanie TRIPS. Zgodnie $\mathrm{z}$ art. 2 ust. 1 TFUE

Jeżeli Traktaty przyznają Unii wyłączną kompetencję w określonej dziedzinie, jedynie Unia może stanowić prawo oraz przyjmować akty prawnie wiążące, natomiast Państwa Członkowskie mogą to czynić wyłącznie z upoważnienia Unii lub w celu wykonania aktów Unii.

Przepis ten należy czytać, zachowując kontekst art. 207 ust. 6 TFUE, który stanowi, że „Wykonywanie uprawnień w dziedzinie wspólnej polityki handlowej, przyznanych niniejszym artykułem, nie narusza podziału kompetencji między

42 Zob. rozważania zawarte w: B. Gotsova, The Gordian Knot of European Union Competence: Commercial Aspects of Intellectual Property After the Judgment in Case C-414/11 Daiichi Sankyo, German Law Journal 2014/15/03, s. 527-528.

43 Pkt 48 wyroku. 
Unią i Państwami Członkowskimi i nie prowadzi do harmonizacji przepisów ustawowych lub wykonawczych Państw Członkowskich, jeżeli Traktaty wykluczają taką harmonizację". Tym samym podział kompetencji zewnętrznych w kontekście TRIPS, co do zasady nie wpływa na podział kompetencji wewnętrznych w tym samym kontekście ${ }^{44}$. Interpretacja przez TSUE przepisów patentowych zawartych w TRIPS może skutkować wpływem postanowień TRIPS na stosowanie norm materialnoprawnych zawartych w Porozumieniu w sprawie Jednolitego Sądu Patentowego (PJSP) w odniesieniu do patentu jednolitego, ponieważ zgodnie z art. 24 ust. 1 lit. d) PJSP orzeka m.in. na podstawie „innych porozumień międzynarodowych mających zastosowanie do patentów i wiążących dla wszystkich umawiających się państw członkowskich”. Mając na uwadze art. 21 PJSP stanowiący, że:

\begin{abstract}
Jako sąd wspólny dla umawiających się państw członkowskich i część ich systemu sądowego Sąd współpracuje z Trybunałem Sprawiedliwości Unii Europejskiej, by zapewnić prawidłowe stosowanie i jednolitą wykładnię prawa Unii, tak jak każdy sąd krajowy, zgodnie w szczególności z art. 267 TFUE. Orzeczenia Trybunału Sprawiedliwości Unii Europejskiej są dla Sądu wiążące
\end{abstract}

można dojść do wniosku, że wnioski o wydanie orzeczenia w trybie prejudycjalnym, skierowane do TSUE przez Jednolity Sąd Patentowy (JSP) w odniesieniu do postanowień dotyczących patentów w TRIPS mogłyby potencjalnie prowadzić do quasi-harmonizacji prawa patentowego w UE.

\title{
6. Zakończenie
}

Trybunał Sprawiedliwości w swoim orzecznictwie wskazał na istotę roli sądów krajowych w odniesieniu do skutku bezpośredniego TRIPS, jednocześnie uznając swoją kompetencję do interpretacji postanowień TRIPS bez względu na to, czy wskazane przepisy wchodzą w zakres kompetencji państw członkowskich, czy Unii. Główną przeszkodą dla uznania przez Trybunał skutku bezpośredniego TRIPS był brak jasności, co do zakresu kompetencji Unii w odniesieniu do ochrony praw własności intelektualnej. Problem ten rozwiązał się wraz z wejściem w życie Traktatu z Lizbony. W nowym stanie prawnym Trybunał

44 Zob. rozważania zawarte w: M. Montana i Mora, The Practical Consequences of the CJEU Judgment of 18 July 2013 Changing Its Doctrine on the Respective Competences of the EU and its Member States to Apply the TRIPS Agreement: Have We Seen the Tip of the Daiichi Iceberg Yet?, International Review of Intellectual Property and Competition Law 2017/48, s. 784-812. 
zmienił swoje stanowisko przedstawione wcześniej w opinii 1/94, uznając, że TRIPS jest w całości objęte obszarem Wspólnej Polityki Handlowej. Niestety kwestia skutku bezpośredniego TRIPS nadal nie została jasno określona poprzez Trybunał, który nie zdecydował się na jednoznaczną wykładnię w tym zakresie. Tym samym trudno jednoznacznie odpowiedzieć na pytanie o skutek bezpośredni TRIPS do czasu, kiedy Trybunał dokona dalszej wykładni tej problematyki w kolejnych orzeczeniach. Wątpliwości rozwiałaby w szczególności sprawa skierowana do Trybunału bezpośrednio na podstawie postanowień TRIPS. Możliwe, że brak jak do tej pory takiego przypadku wynika z faktu, że państwa członkowskie zaimplementowały do prawodawstwa krajowego minimalne standardy ochrony zawarte w TRIPS przez co kwestia jego skutku bezpośredniego straciła na znaczeniu. Jednoznaczne stwierdzenie takiego stanu wymagałoby jednak analizy porównawczej zarówno przepisów, jak również orzecznictwa sądów krajowych, co wykracza poza zakres niniejszego artykułu.

\section{Bibliografia}

\section{Akty prawne}

Dyrektywa 98/84/WE Parlamentu Europejskiego i Rady z dnia 20 listopada 1998 r. w sprawie prawnej ochrony usług opartych lub polegających na warunkowym dostępie, OJ L 320, 28.11.1998 r., s. 54-57.

Rozporządzenie Rady (EWG) nr 1768/92 z dnia 18 czerwca 1992 r. dotyczące stworzenia dodatkowego świadectwa ochronnego dla produktów leczniczych, OJ L 182, 2.7.1992 r., s. 1-5.

Traktat ustanawiający Europejską Wspólnotę Gospodarczą podpisany w Rzymie 25 marca 1957 r.

Traktat z Amsterdamu zmieniający Traktat o Unii Europejskiej, traktaty ustanawiające Wspólnoty Europejskie i niektóre związane z nimi akty podpisany w Amsterdamie dnia 2 października $1997 \mathrm{r}$.

Traktat z Lizbony zmieniający Traktat o Unii Europejskiej i Traktat ustanawiający Wspólnotę Europejską podpisany w Lizbonie dnia 13 grudnia $2007 \mathrm{r}$.

Traktat z Nicei zmieniający Traktat o Unii Europejskiej, traktaty ustanawiające Wspólnoty Europejskie i niektóre związane z nimi akty podpisany w Nicei dnia 26 lutego $2001 \mathrm{r}$.

Ustawa z dnia 19 października 1972 r. o wynalazczości, Dz.U. z 1993 r., nr 26, poz. 117 ze zm.

\section{Opracowania}

Barcz J., W sprawie bezpośredniego skutku przepisów Porozumienia TRIPS $w$ świetle prawa wspólnotowego (I), Europejski Przegląd Sądowy, luty 2006 r., s. 18-31.

Barcz J., W sprawie bezpośredniego skutku przepisów Porozumienia TRIPS $w$ świetle prawa wspólnotowego (II), Europejski Przegląd Sądowy, marzec 2006 r., s. 14-26.

Bourgeois J., The EC in the WTO and Advisory Opinion 1/94: An Echternach Procession, Common Market Law Review 1995/32, s. 763-787. 
Correa C.M., Trade-Related Aspects of Intellectual Property Rights, A Commentary on The TRIPS Agreement, Oxford 2020.

Craig P., de Burca G., EU Law: Text, Cases and Materials, Oxford University Press 2020.

Czajkowska-Dąbrowska M., Ochrona praw autorskich i pokrewnych na podstawie konwencji międzynarodowych, w: J. Barta (red.), System Prawa Prywatnego, t. 13, Prawo autorskie, Warszawa 2013, s. 971-1077.

Czermińska M., Wspólna Polityka Handlowa Unii Europejskiej. Znaczenie dla ochrony jednolitego rynku wewnętrznego i międzynarodowego bezpieczeństwa ekonomicznego, Torun 2019.

Gotsova B., The Gordian. Knot of European Union Competence: Commercial Aspects of Intellectual Property After the Judgment in Case C-414/11 Daiichi Sankyo, German Law Journal 2014/15/03, s. 511-528.

Górski M., Wspólna Polityka Handlowa Unii Europejskiej. Aspekty prawne i instytucjonalne, Warszawa 2012.

Hilf M., The ECJ's Opinion 1/94 on the WTO, No surprise but Wise?, European Journal of International Law 1995/6, s. 245-259.

Mazur G., Wspólna Polityka Handlowa Unii Europejskiej, Warszawa 2017, s. 14-46.

Montana i Mora M., The Practical Consequences of the CJEU Judgment of 18 July 2013 Changing Its Doctrine on the Respective Competences of the EU and its Member States to Apply the TRIPS Agreement: Have We Seen the Tip of the Daiichi Iceberg Yet?, International Review of Intellectual Property and Competition Law 2017/48, s. 784-812.

Nowicka A., Wynalazki i ich ochrona - wybrane aspekty prawne i praktyczne, Prace z Prawa Własności Intelektualnej 2014/126, s. 84-101.

Pires de Carvalho N., The TRIPS Regime of Patent Rights, Hague 2005.

Ryder R.D., Sreenivasulu S., The Economics of Intellectual Property and Economic Entrepreneurship of Copyrights, w: K. Sinha, V. Mahalwar, Copyright Law in the Digidal World. Challenges and Opportunities, Singapore 2017, s. 45-60.

Skubisz R., Glosa do wyroku Naczelnego Sadu Administracyjnego z dnia 8 lutego 2006 r. (sygn. akt II GSK 54/05), Zeszyty Naukowe Sądownictwa Administracyjnego 2006/6, s. 152-162.

Skubisz R., Własność przemysłowa w systemie prawa, w: R. Skubisz (red.), System Prawa Prywatnego, t. 14A, Prawo własności przemystowej, Warszawa 2012, s. 1-97.

Targosz T., Miejsce porozumienia TRIPS w prawie polskim, Kwartalnik Prawa Prywatnego 2005/ $\mathrm{XIV} / 3$, s. 735-763.

Tridimas T., The WTO and OECD Opinions, w: A. Dashwood, Ch. Hillion (red.), The general law of E.C. external relations, Sweet \& Maxwell, 2000, s. 8-60.

du Vall M., Kostański P., Ożegalska-Trybalska J., Podrecki P., Traple E. (red.), Prawo patentowe, Warszawa 2017.

Van den Bossche P., Zdouc W., The Law and Policy of the World Trade Organization, Cambridge University Press 2018.

Weresa M.A. (red.), Własność intelektualna. Wybrane aspekty ekonomiczne, Warszawa 2009.

Wróbel A., Wspólna Polityka Handlowa Unii Europejskiej, Warszawa 2014.

\section{Orzeczenia i opinie}

Opinia Trybunału Sprawiedliwości 1/75 z dnia 11 listopada 1975 r., ECLI:EU:C:1975:145.

Opinia Trybunału Sprawiedliwości 1/76 z dnia 26 kwietnia 1977 r w sprawie projektu umowy o stworzeniu funduszu europejskiego dla żeglugi śródlądowej, ECLI:EU:C:1977:63. 
Opinia Trybunału Sprawiedliwości 1/94 z dnia 15 listopada 1994 r., ECLI:EU:C:1994:384.

Wyrok Trybunału C-22/70 z dnia 31 marca 1971 r., Komisja Wspólnot Europejskich przeciwko Radzie Wspólnot europejskich, ECLI:EU:C:1971:32.

Wyrok Trybunału C-38/73 z dnia 13 grudnia 1973 r. Social Fonds voor de Diamantarbeiders przeciwko NV Indiamex i Feitelijke Vereniging De Belder, ECLU:EU:C:1973:165.

Wyrok Trybunału C-137/12 z dnia 22 października 2013 r., Komisja Europejska przeciwko Radzie Unii Europejskiej, ECLI:EU:C:2013:675.

Wyrok Trybunału C-181/73 z dnia 30 kwietnia 1974 r., R. \& V. Haegeman przeciwko państwu belgijskiemu, ECLI:EU:C:1974:31.

Wyrok Trybunału C-300/98 z dnia 14 grudnia 2000 r. Parfums Christian Dior SA przeciwko TUK Consultancy BV i Assco Gerüste GmbH i Rob van Dijk przeciwko Wilhelm Layher GmbH \& Co. KG i Layher BV, ECLI:EU:C:200:688.

Wyrok Trybunału C-414/11 z dnia 18 lipca 2013 roku w sprawie Daiichi Sankyo Co. Ltd., Sanofi-Aventis Deutschland GmbH przeciwko DEMO Anonymos Viomichaniki kai Emporiki Etairia Farmakon, ECLI:EU:C:2013:520.

Wyrok Trybunału C-431/05 z dnia 11 września 2007 r., Merck Genéricos - Produtos Farmacêuticos Ltd przeciwko Merck \& Co. Inc. i Merck Sharp \& Dohme Ltd, ECLI:EU:C:2007:496.

Wyrok Trybunału w C-21/72 z dnia 12 grudnia 1972 r., International Fruit Company NV i inni przeciwko Produktschap voor Groenten en Fruit, ECLI:EU:C:1972:115.

Wyrok Trybunału w sprawie C-104/81 z dnia 26 października 1982 r., Hauptzollamt Mainz przeciwko C.A. Kupferberg \& Cie KG a.A., ECLI:EU:C:1982:362.

Wyrok Trybunału w sprawie C-53/96 z dnia 16 czerwca 1998 r., Hermès International (société en commandite par actions) przeciwko FHT Marketing Choice BV, ECLI:EU:C:1998:292.

\title{
Źródła internetowe
}

Intangible Capital in Global Value, World Intellectual Property Report 2017, World Intellectual Property Organization, https://www.wipo.int/edocs/pubdocs/en/wipo_pub_944_2017.pdf; stan na 17.12.2020 r.

Montañá M., Spanish Supreme Court clarifies that its case law on TRIPS is not affected by the ECJ Daiichi Judgment, Kluwer Patent Blog, http://patentblog.kluweriplaw.com/2014/02/06/ spanish-supreme-court-clarifies-that-its-case-law-on-trips-is-not-affected-by-the-ecjdaiichi-judgment/\#comments; stan na 7.12.2020 r.

Łukasz STERNOWSKI

\section{"COMMERCIAL ASPECTS OF INTELLECTUAL PROPERTY" AS PART OF THE COMMON COMMERCIAL POLICY - CONSEQUENCES FOR DIRECT EFFECTIVENESS OF TRIPS}

\begin{abstract}
Background: Continuous technological development makes the importance of intellectual property grow, and legal protection of, among others, inventions and pharmaceutical products is increasingly necessary, especially in countries where the economies are based on innovation. In recent years, the Common Commercial Policy of the European Union has been subject to treaty changes, resulting in the evolution of both its subjective and material scope. The nature of the
\end{abstract}


European Union's competence in this area has also been changing together with the change of Treaties' content. One of the most important and at the same time most controversial issues is the direct effect of the TRIPS Agreement in the European Union Member States. The importance of this issue arises from the provisions of the TRIPS Agreement, which guarantee a minimum level of protection of intellectual property rights.

Research purpose: The author aims to determine the scope of the European Union's competence in relation to the TRIPS Agreement. The article's goal is to answer the question: how the evolution of the Common Commercial Policy of the European Union has affected the application of the TRIPS Agreement among the Member States. Moreover, the study aims to clarify whether the TRIPS Agreement has direct effect in the European Union Member States.

Methods: With regard to the treaty provisions, the study mainly uses formal-dogmatic and historical methods. The empirical-legal method was used to examine the case law of the Court of Justice of the European Union.

Conclusions: The nature of the European Communities', and then of the European Union with regard to the Common Commercial Policy, had been changing along with the changes in the provisions of the Treaties. Since the entry of the Lisbon Treaty into force (1.12.2009), the Common Commercial Policy has fallen within the exclusive competence of the European Union and has covered commercial aspects of intellectual property. The jurisprudence of the Court of Justice confirmed that TRIPS falls entirely within the competence of the EU, which may lead to the conclusion that for the assessment of the direct effect of its provisions the union rules apply, rather than the controversy in the previous legal situation, when TRIPS was a socalled mixed agreement. On the other hand, the Court has not decided to challenge the previous jurisprudence in this respect, which may suggest that denying the direct effect of TRIPS remains valid. Nevertheless, the problem lost its practical significance, as the provisions of TRIPS were (after the end of the transitional periods) incorporated into the national law of the Member States.

Keywords: European Union, the Court of Justice of the European Union, Treaty on the Functioning of the European Union, intellectual property law, patent. 